\section{In Memoriam \\ María Ester Albeck (1952-2020)}

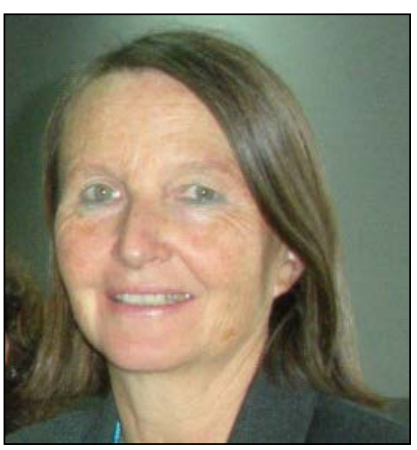

\section{Por Beatriz N. Ventura* y Verónica I. Williams**}

María Ester, Mariette para todos los que la conocían, falleció hace un año, dejando un gran vacío en la arqueología y en quienes la tratamos y quisimos. Hija de migrantes daneses, sus orígenes la ubican en Necochea, y más precisamente en La Dulce, donde en su crianza predominaron la austeridad, la honestidad y la rectitud, valores que la acompañaron a lo largo de su vida.

Estudió en la Facultad de Ciencias Naturales y Museo de la Universidad de La Plata (UNLP), en donde se licenció en Antropología con orientación Arqueología y, posteriormente, en 1993 obtuvo el título de Doctora en Ciencias Naturales dirigida por el Ing. Augusto Cardich con su tesis "Contribución al estudio de los sistemas agrícolas prehispánicos de Casabindo, Puna de Jujuy", que fue un trabajo pionero para nuestra arqueología. Desde 1980 fue becaria Iniciación del CONICET alcanzando la categoría de Investigadora Principal.

A mediados de los años 80 (1986), siendo ya Becaria del CONICET y con lugar de trabajo en la División Arqueología de la UNLP, decidió mudarse a Jujuy, emprendimiento que compartió con otra arqueóloga, Beatriz Cremonte. Se instalaron los primeros años en Tilcara, en la residencia del Instituto Interdisciplinario de Tilcara de la Facultad de Filosofía y Letras de la Universidad de Buenos Aires (FFyL-UBA), bajo la dirección del recordado Guillermo Madrazo. Es allí, en la Quebrada de Humahuaca, donde formó una familia y echó raíces, en Maimará primero y en Uquía después. Continuó realizando sus trabajos de investigación en la Puna jujeña y posteriormente en la quebrada de Humahuaca, siempre desarrollando sus investigaciones con una mirada amplia y abarcadora de las múltiples problemáticas Suramericanas. De allí que fuera la organizadora de diversos Talleres y Simposios en Congresos, entre los que mencionamos el Taller de Costa a Selva en 1992 y, en 2006 junto con otras colegas de la Universidad de Jujuy, el Taller Internacional de Arqueología del NOA y Andes Centro-Sur (TANOA II), donde

* Instituto de Arqueología, Facultad de Filosofía y Letras, Universidad de Buenos Aires (UBA). 25 de mayo 217, $3^{\circ}$ piso (CP C1002ABE) Ciudad Autónoma de Buenos Aires, Argentina. E-mail: beatrizventura2006@yahoo.com.ar

** Universidad de Buenos Aires - Instituto de las Culturas (IDECU), CONICET Universidad de Buenos Aires. Moreno 350 (CP C1091AAH) Ciudad Autónoma de Buenos Aires, Argentina. E-mail: veronicaw33@yahoo.com se reunieron investigadores de Chile, Perú y Bolivia junto a arqueólogos e historiadores argentinos. También formó parte del Comité Organizador del Congreso Nacional de Arqueología Argentina, realizado en Jujuy en 2007.

Fue profesora en la Universidad Nacional de Jujuy dictando Arqueología Argentina, materia cursada por los arqueólogos egresados de esa Universidad, ámbito que le permitió conformar equipos de investigación interdisciplinarios, siendo directora de varias generaciones de investigadores. Su tarea en la formación de recursos humanos fue notable, por lo que Mariette cuenta con el agradecimiento de todos sus becarias, becarios y tesistas.

Fue Directora del Instituto Interdisciplinario Tilcara (FFyL,UBA) entre 1991 y 1995 y miembro de diversas Comisiones Asesoras del CONICET por sucesivos períodos.

Colegas de todo el mundo escucharon sus avances en Congresos Internacionales y Nacionales sobre sus variados temas de investigación que abarcaron los sistemas agrícolas, la percepción del espacio, los vínculos interregionales, la etnohistoria, la historia colonial, la toponimia, la historia oral y genética, la antroponimia y diversos aspectos de la materialidad de la Puna, la quebrada y los valles orientales, entre otros. Numerosas publicaciones dan cuenta de esta rica labor de investigación.

Fue una de las precursoras del estudio de la agricultura prehispánica y los cultivos andinos en la Puna jujeña. En su tesis doctoral desarrolló la primera investigación sobre los diferentes sistemas agrícolas en la Puna de Jujuy y aplicó técnicas de datación tales como la liquenometría.

Integró el equipo que presentó la postulación ante la Unesco para nominar a la Quebrada de Humahuaca como Patrimonio Mundial, participando por la Provincia de Jujuy, al igual que en la postulación Internacional del Qhapaq Ñan. Además, fue vocal de la Comisión Nacional de Museos, Monumentos y lugares históricos representando a Jujuy.

Mariette fue una mujer de carácter, intrépida, que se movía con la misma eficacia en las tareas más disímiles. Con igual seguridad podía llevar a cabo una tarea rural como presidir un jurado de un concurso docente o un Taller Internacional de Arqueología o 
guiar a la reina Margarita II de Dinamarca en su visita al Museo Arqueológico de Tilcara y al Pucara en marzo de 2019.

Más allá de todos los cargos académicos que ocupó, queremos recordarla a través de las historias que nos dejó, de los vívidos relatos de sus primeras campañas, entre ellas la excavación en el Beni, en Bolivia, con sus profesores de la Universidad de La Plata o sus recorridos por distintos sitios arqueológicos del NOA al frente del viejo Citroen que tantas anécdotas brindó a las y los colegas de su generación. Quienes compartimos campañas con ella en Las Pailas en el valle Calchaquí estudiando los canales de riego, en Coctaca en la Quebrada de Humahuaca o en Rodeo Colorado en los valles orientales de Salta investigando los andenes de cultivo, aprendimos mucho a partir de sus amplios conocimientos sobre ambientes, paisajes y los recursos naturales.

Imposible olvidar su memoria detallista, la fuerza con que protegía a sus equipos de investigación y su gran dedicación al trabajo. También, su hospitalidad y sencillez en cada gesto de afecto que no nos permite olvidarla.

En los últimos años le peleó a una cruel enfermedad con una valentía digna de la mayor admiración. Amaba la vida, viajar, su trabajo, su hogar, su familia y amigos. ¡La extrañaremos por siempre! 